FOLIA POMERANAE UNIVERSITATIS TECHNOLOGIAE STETINENSIS

Folia Pomer. Univ. Technol. Stetin., Oeconomica 2017, 335(87)2, 233-244

Paweł RUMNIAK

\title{
JAKOŚĆ KSZTAŁCENIA A POTRZEBY PRACODAWCÓW NA PRZYKŁADZIE PRZEDSIĘBIORSTWA TRANSPORTOWEGO
}

\author{
QUALITY OF EDUCATION AND EMPOLYERS' NEEDS. THE CASE FROM \\ THE TRANSPORTATION COMPANY
}

Katedra Rachunkowości, Controllingu, Informatyki i Metod Ilościowych, Uniwersytet Ekonomiczny we Wrocławiu, ul. Komandorska 118/120, 53-345 Wrocław, e-mail: pawel.rumniak@ue.wroc.pl

Summary. The quality of education and suitability acquired during studies is influenced by many factors. As the principal author points: scientific staff, social skills and practical experience acquired during studies. The author points out the shortcomings in the quality management and the possible pathways for improvement.

Słowa kluczowe: jakość, proces dydaktyczny, wiedza praktyczna.

Key words: quality, teaching process, applied knowledge.

\section{WSTĘP}

Wiedza to podstawowy produkt w procesie edukacyjnym. Każdy student, przekraczając próg uczelni, rzadko zastanawia się nad faktem, iż od tego momentu zaczyna proces inwestowania w rozwój swojej osobistej kariery. W gospodarce jest to nazywane nabywaniem wiedzy, pozyskiwaniem i kształtowaniem know-how, budową reputacji lub po prostu nauką profesjonalnych zachowań biznesowych. Proces ten, jak każdy, ma określone etapy, a jego finałem jest uzyskanie dyplomu ukończenia uczelni i „obietnica” wiedzy i umiejętności dla przyszłego pracodawcy. Absolwent szybko zderza się ze światem pełnym ryzyka oraz czynników, które powodują, że modele zachowań nabyte w trakcie studiów nie przystają do rzeczywistości biznesowej. Bardzo typowym przykładem jest przeniesienie wiedzy teoretycznej z rachunkowości na grunt praktyczny, gdzie księgowość nierzadko pełni funkcje księgowe i finansowe przy wykonywaniu m.in. czynności związanych z zadaniami kadrowo-płacowymi, podatkowymi czy finansowymi, polegającymi na właściwym kreowaniu polityki zarządzania płynnością finansową przedsiębiorstwa. Jakość kształcenia na uczelniach determinuje możliwość dostosowania się do warunków praktycznych i wpływa na umiejętność wykorzystania nabytej wiedzy w pracy zawodowej absolwenta.

Autor niniejszego artykułu, bazując na własnych doświadczeniach, będąc jednocześnie pracownikiem naukowo-dydaktycznym oraz pracując jako dyrektor finansowy $w$ transportowej spółce akcyjnej, przeprowadził analizę porównawczą czynników związanych z jakością kształcenia i wpływających w sposób istotny na wiedzę i umiejętności absolwentów niezbędne w pracy w dziale controllingu w przedsiębiorstwie transportowym. 
Celem artykułu jest analiza priorytetów jakościowych związanych z procesem kształcenia na poziomie akademickim oraz pracodawców wobec absolwentów i jednocześnie oczekiwań kandydatów do pracy.

\section{DETERMINANTY JAKOŚCI W PROCESIE EDUKACYJNYM}

Jakość oznacza zgodność ze wzorcem. W przypadku procesu edukacyjnego jakość oznacza posiadanie wiedzy zgodnej z programem kształcenia. Program kształcenia jest wzorcem wiedzy, jaka powinna być przyswojona przez studentów. Rolą pracowników naukowo-dydaktycznych jest pomoc i wsparcie studentów w realizacji procesu nabywania wiedzy. Pracownicy akademiccy, dzięki swojej wiedzy, kompetencji, umiejętności przekazywania posiadanej wiedzy w znaczny sposób wpływają na jakość kształcenia. Jak podkreślą Wawak i Wawak (2001), czynniki oddziałujące na jakość kształcenia można ująć w czterech grupach, które obejmują:

1) wyposażenie, w tym

a) dostępność miejsc do samokształcenia;

b) dostępność innych źródeł wiedzy;

c) dostępność pomocy naukowych;

d) organizację sal wykładowych, ćwiczeniowych, laboratoriów;

e) bibliotekę - dostępność do literatury krajowej, zagranicznej, możliwości związane ze sprowadzeniem brakującej literatury;

2) pracowników, w tym

a) wykorzystywanie nowoczesnych narzędzi;

b) metody nauczania;

c) promowanie i wspomaganie form samokształcenia;

d) strukturę pracowników naukowych;

e) dostępność dla studentów;

3) metody, w tym

a) metody oceny;

b) sposób tworzenia grup studenckich;

c) metody działania służb administracyjnych;

d) badanie potrzeb i oczekiwań studentów;

e) zabezpieczenie spraw bytowych;

4) program, w tym
a) charakterystykę przedmiotów;
b) obciążenie zajęciami;
c) strukturę programu;
d) elastyczność wyboru profilu.

Można stwierdzić, że jakość kształcenia jest pochodną interakcji zachodzących między studentem a pracownikiem naukowo-dydaktycznym na terenie uczelni lub w ramach posiadanych przez uczelnię zasobów materialnych, finansowych i niematerialnych. O ostatecznej jakości kształcenia decyduje zatem wiele czynników, co jednocześnie ogranicza prawdopodobieństwo osiągnięcia wzorca, tj. pełnej realizacji programu kształcenia. Figlewicz (2002), rozważając kwestie jakości kształcenia, wskazuje, że: 
1) działania organizacji powinny być nastawione na zaspokajanie, a nawet antycypowanie potrzeb klienta; działania projakościowe z jednej strony wynikają z potrzeby świadczenia usług na najwyższym poziomie, z drugiej zaś strony - z potrzeby dostosowania się do wymagań rynkowych; jakość powinna zapewnić akredytacja, natomiast w rzeczywistości procedura akredytacyjna usztywnia programy nauczania i zwiększa czas reakcji uczelni na zmieniające się potrzeby rynku pracy. Tak pojmowana jakość osłabia pozycję konkurencyjną uczelni i prowadzi do wypaczenia znaczenia jakości w procesie edukacji;

2) uczelnie powinny zajmować dominującą pozycję na rynku i pełnić funkcję przywódczą, przez którą należy rozumieć posiadanie przez liderów organizacji spójnych jednolitych celów; podejście to można rozpatrywać w szerszym i w węższym kontekście; znaczenie szersze wiąże się z rolą uczelni na lokalnym rynku - jako pracodawcy oraz jako jednostki będącej wzorcem do naśladowania w różnych obszarach; w węższym kontekście zarządzanie uczelnią i jej poszczególnymi komórkami merytorycznymi powinno opierać się na liderach wzbudzających powszechny szacunek swoich pracowników;

3) zaangażowanie w dbanie o jakość wszystkich jednostek organizacyjnych powinno być pełne; zaangażowanie jest związane z motywacją do działania poszczególnych członków organizacji; bez właściwego systemu motywacyjnego osiągnięcie właściwego poziomu zaangażowania w dbanie o jakość nie będzie możliwe;

4) pełne powinno być zaangażowanie członków organizacji w realizację jej celów strategicznych oraz w dbanie o jakość usług na wszystkich jej szczeblach; realizacja tego postulatu, poza wskazaną w poprzednim punkcie motywacją, wiąże się ze znajomością strategii jednostki, która powinna być w odpowiedni sposób komunikowana załodze;

5) podejście do realizowanych zadań powinno mieć charakter procesu; procesem nazywamy każde działanie, w wyniku którego stan wejściowy jest przekształcany w stan wyjściowy; efektem tego działania jest wyrób definiowany jako wynik procesu; istnieją 4 ogólne kategorie wyrobu: przedmiot materialny, wytwór intelektualny, usługi i materiały przetworzone; w przypadku jakości kształcenia mamy do czynienia z dwoma kategoriami wyrobu z wytworem intelektualnym oraz z usługą edukacyjną; uczelnia, chcąc działać skutecznie, powinna dokonać identyfikacji procesów i powiązań między nimi, wpływających na funkcjonowanie całej organizacji;

6) systemowe powinno być podejście do zarządzania; uczelnia to specyficzna jednostka, która - jak każda inna - jest zarządzana, ale przy okazji uczy, jak powinno się zarządzać; niestety, bardzo często uczelnie nie są wzorem do naśladowania, jak powinno się zarządzać; stąd bierze się potoczna opinia o jakości kadr naukowo-dydaktycznych, o teoretyzowaniu i o braku umiejętności praktycznych; niestety, w kręgach praktyków powszechne jest przekonanie o braku umiejętności rozwiązywania praktycznych problemów przez pracowników naukowo-dydaktycznych, z czego m.in. bierze się niechęć do współpracy przedsiębiorstw z uczelniami;

7) ważne są doskonalenie i samodoskonalenie; obszar doskonalenia kadr na większości uczelni opiera się na samodoskonaleniu, lecz brakuje jasno wytyczonych ścieżek postępowania w trakcie całej kariery naukowej; kierownicy katedr lub innych komórek merytorycznych sporadycznie tworzą budżety szkoleniowe i wysyłają pracowników na szkolenia pogłębiające lub aktualizujące ich wiedzę, co wiąże się z permanentnym 
ograniczaniem środków finansowych przeznaczanych na komórki merytoryczne; kierownicy tych komórek sprowadzają swoją działalność zarządczą do dwóch obszarów - do realizowanej dydaktyki oraz do oceny liczby opublikowanych artykułów przez poszczególnych pracowników komórek merytorycznych; nie uwzględnia się w ocenie pracowników ich szerokich kontaktów z przedstawicielami praktyki gospodarczej, umiejętności łączenia wiedzy teoretycznej z praktycznym działaniem i rozwiązywaniem problemów przedsiębiorstw, występowania pracowników naukowo-dydaktycznych w sprawach sądowych jako biegłych; system oceny pracowników naukowo-dydaktycznych nie uwzględnia tych aspektów działalności;

8) ważna jest atmosfera pracy na polskich uczelniach, które nie uczą pracy zespołowej; większość jednostek merytorycznych jest zbiorem indywidualności, które nie potrafią działać zespołowo, co wpływa znacząco na pracę w organizacji. Nie ma otwartych relacji, panuje atmosfera negatywnego współzawodnictwa i porównywania się $z$ innymi pracownikami pod względem liczby punktów w ocenie rocznej itp.; nie sprzyja to pozytywnej atmosferze w pracy.

Grudowski i Lewandowski (https://www.google.pl/url?sa=t\&rct=j\&q=\&esrc=s\&source=web\&cd) wskazują następujące determinanty jakości kształcenia:

1) zewnętrzne, w tym

a) położenie jednostki realizującej proces dydaktyki,

b) chłonność lokalnego rynku pracy,

c) uwarunkowania prawne,

d) budżet jednostki,

e) dyscyplinę naukową jednostki,

2) wewnętrzne, w tym

a) otwartość studentów,

b) charakter treści programowych,

c) system motywacji studentów i pracowników,

d) samoświadomość interesariuszy procesu kształcenia w zakresie orientacji projakościowej,

e) wyposażenie placówek realizujących proces kształcenia,

f) mobilność uczestników procesu kształcenia.

Trudno nie odnieść wrażenia, że autorzy nie zauważają pewnych dość oczywistych determinant, takich jak dynamika zmian rynku pracy, który potencjalnie ma wchłaniać absolwentów uczelni. Im gorsze jest dopasowanie systemu kształcenia do potrzeb rynkowych, tym większa jest liczba bezrobotnych z wyższym wykształcenie. Jeśli nawet zostanie zachowany wysoki poziom kształcenia, to niedostosowanie liczby absolwentów do liczby miejsc pracy spowoduje powstawanie zjawiska bezrobocia.

Piasecka (2011) w swoich badaniach nad jakością kształcenia na uczelniach wskazuje, że podejmują one także działania projakościowe, jak:

1) selekcja kandydatów na studia ( $49,10 \%$ badanych);

2) ocena kompetencji pracowników naukowo-dydaktycznych (94,50\% badanych);

3) zakup nowego wyposażenia ( $94,50 \%$ badanych);

4) wprowadzanie zmian do programów nauczania ( $96,40 \%$ badanych);

5) badanie zadowolenia studentów (85,50\% badanych); 
6) dostosowywanie programów nauczania do zmieniających się wymagań klientów $(76,40 \%$ badanych);

7) współpraca z uczelniami zagranicznymi ( $80 \%$ badanych);

8) współpraca z pracodawcami (76,40\% badanych).

Trudności związane z rozwojem szkolnictwa wyższego zauważył Szumlakowski (2013), wskazując, że:

1) europejskie uczelnie znajdują się w stanie kryzysu, który polega na niedostatecznym wykorzystaniu potencjału tkwiącego w kadrze akademickiej oraz w studentach; niepokojącym zjawiskiem nie tylko w Europie, ale także w USA i w Kanadzie jest pojawienie się dużej grupy bezrobotnych z wyższym wykształceniem; stopa bezrobocia dla populacji z wyższym wykształceniem w latach 2010-2014 kształtowała się w granicach 5,0-6,2\% i wykazuje tendencję wzrostową;

2) umasowienie w Polsce szkolnictwa wyższego spowodowało, że sytuacja osób, które ukończyły studia wyższe jest taka sama jak sytuacja osób z wykształceniem średnim, co jest spowodowane dynamicznym rozwojem prywatnego szkolnictwa wyższego; często zdobyte przez studentów wykształcenie wyższe nie jest adekwatne do popytu na określone zawody w zmieniającej się dynamicznie polskiej gospodarce; ponadto program i kierunki studiów są niedopasowane do wymagań rynkowych;

3) w krótkiej perspektywie czasowej nie da się określić znaczenia posiadania wykształcenia wyższego w Polsce przez poszczególne jednostki oraz jego wpływu na gospodarkę narodową;

4) w kształceniu na poziomie szkolnictwa wyższego należy znieść test jako formę weryfikacji zdobytej przez studenta wiedzy na rzecz egzaminów ustnych i opisowych;

Bez względu na podejście do klasyfikacji czynników determinujących jakość nauczania wyraźnie widać, że uczelnie w dążeniu do poprawy jakości koncentrują się głównie na obszarach związanych z:

1) bazą materialną i niematerialną uczelni;

2) badaniem zadowolenia studentów;

3) weryfikacją dostosowania programów nauczania do potrzeb rynkowych;

4) oceną kadry dydaktyczno-naukowej.

W systemach jakości nie ma miejsca na zasadnicze ogniwo, którym jest pracownik akademicki; brakuje w tym wypadku przede wszystkim:

1) jasnych systemów wsparcia pracowników naukowo-dydaktycznych w procesie ich rozwoju zawodowego (zdobywanie kolejnych stopni i tytułów naukowych);

2) motywacyjnego systemu wynagradzania;

3) systemu zwiększania kompetencji i umiejętności pracowników naukowych, związanego m.in. z systemem szkoleń pracowników, lub system ten jest szczątkowy;

4) analizy przez pracodawcę potrzeb pracowników naukowych;

5) działań stwarzających podstawy prac zespołowych.

Te oraz inne czynniki ujemnie wpływają na jakość kształcenia i bez względu na to, jak dobrą i nowoczesną bazą edukacyjną będzie dysponowała uczelnia, jakie programy nauczania oraz jak często będzie badana satysfakcja studentów, a także pracownicy naukowo-dydaktyczni, bez inwestycji w zasoby ludzkie żaden system jakości lub system zarządzania jakościowego nie będzie skuteczny. 


\section{JAKOŚĆ ZASOBÓW LUDZKICH JAKO PODSTAWA SUKCESU EDUKACYJNEGO}

Bez względu na wybór klasyfikacji determinant procesu kształcenia najważniejsi w procesie edukacji zawsze będą ludzie, czyli pracownik naukowo-dydaktyczny, oraz student jako odbiorca usługi edukacyjnej. To od jakości kadr przede wszystkim zależy sukces uczelni. Michałek (2005) do czynników wpływających na kompetencje i umiejętności kadry naukowo-dydaktycznej zaliczył istotne wady systemu rekrutacji i rozwoju kadry, wskazując na:

1) długą i „ciernistą” drogę awansu od magistra asystenta do profesora zwyczajnego;

2) uzyskiwanie samodzielności naukowej na ogół w późnym wieku;

3) wymuszanie fikcyjnych konkursów w przypadku każdego stanowiska;

4) brak obiektywnych kryteriów awansu na poszczególne stanowiska, w szczególności zaś profesorskie;

5) zasadę karania zamiast nagradzania.

Autor niniejszego artykułu zauważa następujące wady funkcjonowania systemu edukacji wyższej, wpływające negatywnie na jakość kadr dydaktyczno-naukowej:

1) brak motywacyjnego systemu wynagradzania - istniejący system wynagradzania premiuje staż pracy jako zasadniczy czynnik różnicujący poziom wynagrodzenia, co zniechęca absolwentów do ubiegania się o stanowiska asystentów; średnie wynagrodzenie w przedsiębiorstwach, a w szczególności w sektorze prywatnym, jest zdecydowanie bardziej atrakcyjne niż na stanowiskach akademickich; zupełnie kuriozalne wnioski wynikają z porównania stawek wynagradzania kadr profesorskich ze stawkami, jakie osiągają np. maszyniści pojazdów trakcyjnych pracujący w przedsiębiorstwach kolejowych, wobec których pracodawcy wymagają wykształcenia średniego oraz posiadania prawa kierowania pojazdem trakcyjnym - pełen cykl szkoleniowy trwa 4 lata szkoleń połączonych z praktyką zawodową;

2) preferowany system zatrudniania pracowników na etatach naukowo-dydaktycznych, co znacząco wpływa na zakres realizowanych zadań. Częste przekraczanie pensum rocznego, przeciążenie godzinami dydaktycznymi, powtarzalność realizowanych przedmiotów powodują, że jakość prowadzonych zajęć znacznie spada; pracownik w sposób od siebie niezależny zaczyna posługiwać się skrótami myślowymi, często niezrozumiałymi dla studentów, co ujemnie wpływa na jakość przekazu treści; położenie większego nacisku na wymiar naukowy i odciążenie pracowników naukowych poprzez zmniejszenie godzin dydaktycznych jest jednym ze sposobów na uatrakcyjnienie zajęć i zwiększenie atrakcyjności przekazywanych treści; tym samym należy rozważyć możliwość powstania na uczelniach etatów dydaktycznych oferowanych np. zainteresowanym praktykom z różnych dziedzin gospodarczych;

3) brak inwestycji w kapitał intelektualny przez uczelnie; kierujący uczelnią z założenia nie uwzględniają w budżetach katedr lub instytutów środków finansowych przewidzianych na rozwój pracowników; nierzadko pracownicy naukowo-dydaktyczni w swojej długoletniej karierze naukowej nie są kierowani przez swoich przełożonych na szkolenia, co powoduje, że pracownicy korzystają z wiedzy pozyskanej we własnym zakresie, a jedyna forma jej weryfikacji ma miejsce na konferencjach naukowych, przy czym nie jest to wiedza weryfikowana praktycznie; wskutek takiego postępowania powstaje odizolowany świat 
naukowy, który sam tworzy problemy i sam wskazuje, jak należy je rozwiązać; nie można jednak zapominać, że ci sami ludzie mają codziennie kontakt ze studentami, których uczą praktycznego zawodu, a przekazane im umiejętności będą później wykorzystywane w ich codziennej pracy;

4) brak kontaktu z praktyką - uczelnia jako instytucja bardzo często nie pomaga lub nie wspiera pracowników naukowo-dydaktycznych w ich dążeniu do pozyskania wiedzy praktycznej z dziedziny, w której się specjalizują. Sztuczne bariery zawarte w statutach uczelni - zabraniające pracy poza uczelnią - powodują oderwanie teorii od praktyki. Ekstremalnym przykładem jest podejście jednej z wrocławskich uczelni technicznych, która wręcz zabrania swoim pracownikom naukowo-dydaktycznym pracy w gospodarce, nie zabrania natomiast pracy na innych uczelniach w ramach drugiego etatu lub w ramach umów cywilno-prawnych, co dowodzi, że zarządzanie uczelnią w ujęciu historycznym zostało bardzo wypaczone i że to, co powinno być priorytetem (tj. wysokiej jakości kadra zarówno pod względem teoretycznym, jak i praktycznym), nie jest istotne;

5) wymiana międzynarodowa, która jest uzależniona od „operatywności” szefa katedry lub kierownika instytutu; niestety, nie jest rzadkością, że kierownictwo jednostek naukowych wymaga od swoich pracowników więcej niż od siebie samych; dobrym przykładem jest położenie nacisku na rozwój międzynarodowego dorobku naukowego młodych pracowników nauki; jest to oczywiście bardzo dobry kierunek, ale bardzo często decydenci sami nie mają w swoim dorobku zbyt wielu pozycji opublikowanych poza granicami kraju, a jeśli już mają, to są to publikacje $z$ lat $80 \mathrm{w}$ czasopismach lub materiałach naukowych $\mathrm{w}$ jednym z byłych krajów bloku socjalistycznego; nie jest to, niestety, dobry przykład dla młodych kadr, które - jak w każdej jednostce - potrzebują liderów oraz przełożonych, których będą szanowali z racji ich dokonań zawodowych; drugim istotnym aspektem związanym z wymianą międzynarodową jest znajomość języków obcych; system edukacji językowej wciąż jest nieprzemyślany i realizowany jedynie na zasadzie konieczności programowej; każdy student, a później absolwent - pracownik naukowo-dydaktyczny jest skazany na własną inicjatywę w zakresie zdobywania umiejętności językowych; pracodawca bardzo często nie widzi potrzeby edukacji swoich kadr, natomiast stawia kolejne wymagania związane z rozwojem międzynarodowym, karząc za brak umiejętności językowych i nie wynagradzając za ich posiadanie.

Jądrem systemu zarządzania jakością jest człowiek. Od jego kompetencji, wiedzy i umiejętności zależy, czy zostanie osiągnięty cel kształcenia. Stosowany sposób zarządzania uczelniami, niestety, bardzo często pomija to ogniwo, spycha na dalszy plan, co powoduje, że pracownicy naukowo-dydaktyczni są zostawieni sami sobie i praktycznie od pierwszego dnia pracy na uczelni są skazani na samokształcenie. To od ich własnej operatywności zależy poziom profesjonalizmu, który osiągną. Na uczelniach nie funkcjonują komórki zarządzani zasobami ludzkimi (HR) lub ich funkcje są wypaczone. Organizacja uczelni właściwie nie uległa większym zmianom w ostatnich kilkunastu latach i nadal nie widać, żeby takie zmiany mogły nadejść. Łatwiej jest wdrożyć kolejny system oceniający i sankcyjny, niż prowadzić konsekwentną politykę zarządzania zasobami ludzkimi, co - niestety - stawia pod znakiem zapytania skuteczność każdego systemu zarządzania jakością. 


\section{OCZEKIWANIA PRACODAWCÓW WOBEC ABSOLWENTÓW WYŻSZYCH UCZELNI}

Oczekiwania pracodawców nie są spełniane mimo deklaracji, że ponad $76 \%$ badanych przez Piasecką (2011) jednostek dostosowuje swoje programy do potrzeb rynku. Uczelnie nie prowadzą systematycznego badania potrzeb rynku, skupiają się na wewnętrznych problemach i gubią zasadniczy cel edukacyjny. Pracodawcy w większości przypadków oczekują, że ich przyszły pracownik:

1) będzie wyposażony w odpowiednią wiedzę, którą potrafi wykorzystać w codziennej pracy;

2) będzie otwarty na nową wiedzę, potrafi ją zdobywać i przede wszystkim będzie chciał ją zdobywać;

3) będzie informował pracodawcę o napotkanych problemach, a nie będzie je obchodził, tuszował lub ukrywał, co w konsekwencji spowoduje zwielokrotniony powrót problemów wówczas w ich rozwiązanie będzie musiała być zaangażowana większa liczba osób;

4) będzie samodzielny i nie będzie się bał podejmować decyzji związanych ze swoimi kompetencjami, a w przypadku błędnej decyzji potrafi się do niej przyznać;

5) będzie potrafił współpracować z innymi pracownikami;

6) będzie komunikatywny i otwarty na nowe rozwiązania.

Orczykowska (2006) wymienia następujące istotne kompetencje efektywnych pracowników:

1) umiejętność komunikacji;

2) orientację na cele/wyniki;

3) skupianie się na kliencie;

4) pracę zespołową;

5) inspirujące przywództwo;

6) planowanie i organizowanie;

7) świadomość handlową;

8) elastyczność;

9) pobudzanie do rozwoju innych;

10) umiejętność negocjacji i rozwiązywania problemów.

W podanych kompetencjach nie ma właściwie miejsca na wiedzę fachową lub pracodawcy zakładają, że tę wiedzę pracownik już posiada. Orczykowska (2006), cytując badania AIESEC, pisze, że o zatrudnieniu konkretnego pracownika decydują następujące czynniki: znajomość języków obcych (80\%), odbycie pozauczelnianych kursów i szkoleń świadczących o chęci doskonalenia swoich umiejętności $(76 \%)$, wysoka średnia ocen $(51 \%)$, posiadanie prawa jazdy (33\%), stypendia i nagrody (25\%). Badania UNESCO (Orczykowska 2006) wskazują, iż pracodawcy w jednakowym stopniu oczekują:

1) wiedzy ogólnej;

2) wiedzy praktycznej (know-how);

3) umiejętności społecznych i komunikacyjnych, takich jak praca w zespole i budowanie stosunków międzyludzkich, perswazja i wywieranie wpływu na innych, samokierowanie, inspirujące przywództwo, znajomość języków obcych, orientacja biznesowa, dostrzeganie szczegółów, motywacja, zaangażowanie, wytrwałość w dążeniu do celu oraz elastyczność. 
Nie jest zatem prawdą, że pracodawcy oczekują gotowego produktu w postaci absolwenta idealnego. Oczekują, że ich przyszły pracownik zaangażuje się w pracę i będzie wykonywał swoje czynności najlepiej jak potrafi. Tymczasem absolwenci uczelni bardzo często stawiają swoim przyszłym pracodawcom bardzo wysokie wymagania finansowe oraz żądają dodatkowych benefitów w postaci pakietów socjalnych, bezpłatnej opieki medycznej czy wyposażenia w narzędzia pracy, takie jak samochód, komputer niestacjonarny lub telefon komórkowy.

\section{POSTRZEGANIE JAKOŚCI KSZTAŁCENIA PRZEZ PRYZMAT KOMÓRKI CONTROLLINGU W PRZEDSIĘBIORSTWIE TRANSPORTOWYM}

Komórka controllingu w analizowanym przedsiębiorstwie powstała na początku 2015 roku. Był to efekt zmian organizacyjnych zapoczątkowanych w połowie roku 2014, lecz niezwiązanych z restrukturyzacją przedsiębiorstwa wynikającą z jego złego stanu. Sytuacja przedsiębiorstwa była bardzo stabilna, wynik finansowy pozytywny - wysoki jak na spółkę z sektora transportowego. Początkowo zadania dyrektora finansowego wiązały się z porządkowaniem ewidencji i przetwarzaniem kosztów oraz narzędzi informatycznych wykorzystywanych w tym celu. Z uwagi na to, że eksploatowany system F-K w spółce został oceniony jako mało elastyczny, a wprowadzenie pożądanych zmian wiązałoby się ze znacznymi nakładami, dyrekcja przedsiębiorstwa zdecydowała się na inne rozwiązanie. Celem nadrzędnym było uniezależnienie się od dostawcy oprogramowania F-K oraz przejście na bardziej elastyczne rozwiązania opracowane na bazie arkusza kalkulacyjnego i języka SQL.

Dyrektor finansowy rozpoczął rekrutację na stanowisko przyszłego controllera i docelowo kierownika komórki controllingu w spółce. Wstępne oczekiwania wobec przyszłego pracownika dotyczyły:

1) znajomości teoretycznej i praktycznej rachunkowości finansowej;

2) znajomości teoretycznej i praktycznej rachunku kosztów i rachunkowości zarządczej;

3) znajomości podstaw controllingu;

4) znajomości podstaw pracy w środowisku Excel, w tym podstaw programowania visual basic, podstaw sql;

5) doświadczenia w zarządzaniu ludźmi.

Na ogłoszenie zareagowało 17 osób:

1) grupa 1 - osiem osób, które nigdy nie pracowały w controllingu; okres od ukończenia studiów był krótszy niż rok;

2) grupa 2 - cztery osoby, które miały doświadczenie w controllingu, w tym dwie, które kończyły studia podyplomowe z controllingu, a ich doświadczenie zawodowe było dłuższe niż rok;

3) grupa 3 - pięć osób, które nie pracowały w controllingu, okres od ukończenia studiów wynosił ponad rok, jedna z osób miała doświadczenie na stanowisku kierowniczym.

Po odbyciu wstępnych rozmów kwalifikacyjnych wytypowane zostały trzy osoby - dwie z grupy 2 i jedna z grupy 3 . Z grupy pierwszej nie został zaakceptowany żaden kandydat ponieważ osoby $z$ tej grupy cechowały się:

1) niskimi kompetencjami i niewielką wiedzą z wymaganych obszarów - pomimo ukończenia w większości przypadków uczelni o profilu ekonomicznym; 
2) brakiem determinacji w dążeniu do rozwiązania trudnych problemów (nie potrafili wykonać powierzonego im zadania);

3) słabą komunikatywnością;

4) podatnością na stres;

5) odmienną od deklarowanej znajomością narzędzi informatycznych;

6) nieumiejętnością pracy w grupie;

7) brakiem umiejętności organizowania i planowania działań;

8) czynnik materialnym, który był zasadniczym elementem motywacyjnym.

Kandydaci wybrani z grupy 2 charakteryzowali się bogatą wiedzą narzędziową, wiedzą z zakresu controllingu, natomiast nie posiadali wiedzy z zakresu rachunkowości oraz nie posiadali doświadczenia w kierowaniu ludźmi. Kandydaci preferowali pracę samodzielną, niekoniecznie pod bezpośrednim nadzorem. Kandydat z grupy 3 posiadał odpowiednią wiedzę z zakresu rachunkowości, nie posiadał wiedzy narzędziowej (jedynie podstawy obsługi arkusza kalkulacyjnego), ale za to miał bogate doświadczenie w zarządzaniu ludźmi. Kandydat wykazał się najlepszymi umiejętnościami pracy w grupie, przewodzenia w grupie oraz wysoką odpornością na stres.

Cały proces rekrutacji wykazał, że absolwenci:

1) nie mają odpowiedniego przygotowania do pełnienia funkcji kierowniczych;

2) posiadają wiedzę teoretyczną nieugruntowaną, chaotyczną, która nie daje im żadnej przewagi konkurencyjnej, a w niektórych przypadkach powoduje poważne problemy z identyfikacją problemów i nie pozwala na racjonalne spojrzenie na rzeczywiste problemy;

3) nie posiadają żadnego doświadczenia ze studiów - mimo odbycia stażu dyplomowego w trakcie pisania pracy magisterskiej;

4) mają poważne problemy $z$ podejmowaniem decyzji lub podejmują decyzje w sposób nieprzemyślany;

5) nie potrafią współpracować w grupach, nie potrafią pełnić ról w grupach, bardzo łatwo podporządkowują się i nie zabierają głosu w dyskusji;

6) są niekomunikatywni, nie potrafią racjonalnie argumentować.

Z uwagi na istotne braki kompetencyjne oraz umiejętności pozostałych kandydatów wybrany został kandydat z grupy 3, który posiadał ogólną wiedzę praktyczną oraz wykazał się umiejętnościami społecznymi niezbędnymi do właściwego kierowania komórką controllingu. Jednak najważniejszym kryterium wyboru były umiejętności społeczne, ponieważ są one trudne do zdobycia. Wiedza narzędziowa oraz praktyczna z zakresu controllingu może zostać pozyskana w trakcie procesu wdrażania kolejnych etapów systemu controllingu w spółce.

\section{PODSUMOWANIE}

Doświadczenia autora oraz przywołanie w artykule wyniki badań wskazują, że zasadniczym obszarem, który w pierwszej kolejności powinien być poddany zarządzaniu jakościowemu na uczelniach, jest obszar umiejętności społecznych. Programy nauczania zawierają wiele specjalistycznych przedmiotów powiązanych ze specjalizacją i z kierunkiem studiów. Nie ma jednak w tych programach miejsca na przedmioty, które pozwalają przyszłym absolwentom zaprezentować się pozytywnie od strony umiejętności społecznych. Są to bardzo ważne zagadnienia, w szczególności dla studentów kierunków ekonomicznych, którzy w trakcie rozmów kwalifikacyjnych są sprawdzani właśnie pod tym kątem. 
Drugim obszarem, który jest równie istotny, jest kontakt z praktyką gospodarczą. Poziom współpracy uczelni z gospodarką jest niewystarczający. Bardzo często studenci, nie mając możliwości kontaktu z praktyką gospodarczą, są zmuszeni do pisania prac magisterskich czysto teoretycznych lub opartych na danych ujawnianych przez przedsiębiorstwa w mediach. Akceptowanie tego przez uczelnie prowadzi do oderwania procesu kształcenia od życia gospodarczego, w wyniku czego absolwenci uczelni nie są właściwie przygotowani do wejścia na rynek pracy.

Trzecim obszarem istotnym z punktu widzenia jakości procesu kształcenia są pracownicy akademiccy. Wskazane w niniejszym artykule istotne czynniki, mające wpływ na jakość kadry naukowo-dydaktycznej, powinny być w pierwszej kolejności rozpatrzone przez kierujących uczelniami. Ignorowanie właściwego zarządzania zasobami ludzkimi prowadzi m.in. do powstawania na uczelniach luk pokoleniowych, zatrudniania osób, dla których praca na uczelni jest alternatywą dla bezrobocia, minimalistycznego podejścia do wykonywanych obowiązków służbowych, pracy na wielu etatach dydaktycznych (w jednostkach konkurencyjnych!) i wielu innych, wręcz patologicznych, zachowań.

\section{PIŚMIENNICTWO}

Figlewicz R. 2002. Kompleksowe zarządzanie jakością kształcenia w szkolnictwie wyższym na przykładzie Wyższej Szkoły Humanistyczno-Ekonomicznej w Łodzi. Łódź, OW WSHE, 7-12.

Grudowski P., Lewandowski K. Pojęcie jakości kształcenia i uwarunkowania jej kwantyfikacji w uczelniach wyższych, https://www.google.pl/url?sa=t\&rct=j\&q=\&esrc=s\&source=web\&cd, dostęp: październik 2016.

Michałek R. 2005. Modele kształcenia kadry naukowej. Inż. Rol. 7, 12.

Orczykowska A. 2006. Szkolnictwo wyższe a wymagania rynku pracy. Nauka Szkol. Wyż. 2(28), 57.

Piasecka A. 2011. Wybrane aspekty zapewnienia jakości kształcenia w edukacji na poziomie wyższym. Zesz. Nauk. Ostroł. Tow. Nauk.1(25), 545.

Szumlakowski R. 2013. Wady i zalety umasowienia szkolnictwa wyższego w Polsce. Pr. Nauk. Wydz. Pr. Adm. Ekon. UWroc. 22, 201-205.

Wawak T., Wawak S. 2001. Polemiczny głos w sprawie jakości kształcenia w Polsce na przykładzie nauk ekonomicznych. Probl. Jakości 10, 28. 
